\title{
Proteolytic behavior of isolated Pseudomonas spp. from refrigerated raw milk in different concentrations and storage temperatures
}

\section{Comportamento proteolítico de Pseudomonas spp. isoladas de leite cru refrigerado em diferentes concentrações e temperaturas de estocagem}

\author{
Ana Cristina Pinesso Ribeiro ${ }^{1}$; Samera Rafaela Bruzaroski²; \\ Flavia de Almeida Bergonse Pereira ${ }^{1}$; Fernanda Gonzales Paião ${ }^{3}$; Regina Célia \\ Poli-Frederico ${ }^{4}$ J Joice Sifuentes dos Santos ${ }^{5}$; Elsa Helena Walter de Santana ${ }^{5 *}$
}

\begin{abstract}
The objective of the work was to evaluate the multiplication capacity and proteolytic activity of different Pseudomonas spp. cell counts inoculated in milk and storaged under different temperature. Strains isolated from refrigerated raw milk (RRM) were confirmed at genus level by Polymerase Chain Reaction (PCR). The Pseudomonas spp. was cultured in cephalothin-sodium fusidate-cetrimide (CFC) agar-base $\left(30^{\circ} \mathrm{C}\right.$ for $\left.48 \mathrm{~h}\right)$ until it reached $2 \log$ and $6 \log \mathrm{CFU} \mathrm{mL} \mathrm{m}^{-1}$. Three of eight strains confirmed as Pseudomonas spp. were inoculated in sterile reconstituted whole milk powder and incubated at $2^{\circ} \mathrm{C}$, $4^{\circ} \mathrm{C}$, and $8^{\circ} \mathrm{C}$ for $96 \mathrm{~h}$. Primary proteolysis indices was determined by the Kjeldahl method. When taking into account the effect of storage time in Pseudomonas spp. population, it was found that the initial population $(2 \log \mathrm{CFU} \mathrm{mL}-1)$ showed significant difference in growth rates only from $0 \mathrm{~h}$ to 24 $\mathrm{h}$, keeping at the same levels along $96 \mathrm{~h}$. When a higher initial population was incubated (6 log CFU $\mathrm{mL}^{-1}$ ), it was not observed a significant difference for times tested. Related to the effect of storage time in proteolysis index, it was not observed a significant difference in samples inoculated with 2 and 6 log CFU $\mathrm{mL}^{-1}$ Pseudomonas spp. When we analyzed the influence of storage temperature on the bacterial multiplication, there was a significant difference in the Pseudomonas spp. population only between $2^{\circ} \mathrm{C}$ and $8^{\circ} \mathrm{C}$ after $96 \mathrm{~h}$ of milk storage with $2 \log \mathrm{CFU} / \mathrm{mL}$ of initial inoculum. If we consider the temperature effect in the primary proteolysis index, there were significant differences at the inoculum of $2 \log \mathrm{CFU} \mathrm{mL}{ }^{-1}$ where the primary proteolysis at $24 \mathrm{~h}$ was lower at $2^{\circ} \mathrm{C}$ than at $8^{\circ} \mathrm{C}$. Low temperatures or short storage time had no influence on Pseudomonas spp. enumeration or in the primary proteolysis index when high initial contaminations are observed. At lower Pseudomonas spp. initial population, the smaller storage time tested influenced the population control, and linked with the reduction in the storage temperature, lower proteolysis index were observed.
\end{abstract}

Key words: Storage. Protease. Psycrotrophic. Quality.

${ }^{1}$ Discente, Mestrado em Ciência e Tecnologia do Leite e Derivados, Universidade Norte do Paraná, UNOPAR, Londrina, PR, Brasil. E-mail: ana.pinesso@gmail.com

2 Discente, curso de Medicina Veterinária, Campus Piza, UNOPAR, Londrina, PR, Brasil. E-mail: samera.rafaela@hotmail.com

${ }^{3}$ Pesquisadora, Mestrado em Ciência e Tecnologia do Leite e Derivados, UNOPAR, Londrina, PR, Brasil. E-mail: fergonzalesp@ hotmail.com

${ }^{4}$ Prof ${ }^{\mathrm{a}}$, Mestrado em Ciências da Reabilitação, UNOPAR, Londrina, PR, Brasil. E-mail: reginafrederico@yahoo.com.br

5 Prof ${ }^{\text {as }}$, Mestrado em Ciência e Tecnologia do Leite e Derivados, UNOPAR, Londrina, PR, Brasil. E-mail: joice.sifuentes@gmail. com; elsahws@hotmail.com

* Author for correspondence 


\section{Resumo}

O objetivo deste trabalho foi avaliar a capacidade de multiplicação e a atividade proteolítica de diferentes populações de Pseudomonas spp. inoculadas em leite e estocadas em diferentes temperaturas. Cepas isoladas de leite cru refrigerado (LCR) tiveram o gênero confirmado pela Reação em Cadeia da Polimerase (PCR). Pseudomonas spp. foram isoladas em ágar pseudomonas adicionado de cephalothinsodium fusidate-cetrimide $\left(30^{\circ} \mathrm{C}\right.$ por $\left.48 \mathrm{~h}\right)$ até atingir as populações de $2 \log$ e $6 \log \mathrm{UFC} \mathrm{mL} \mathrm{L}^{-1}$. Três de oito cepas confirmadas como Pseudomonas spp. foram inoculadas em leite em pó integral reconstituído esterilizado e incubadas a $2^{\circ} \mathrm{C}, 4^{\circ} \mathrm{C}$ e $8^{\circ} \mathrm{C}$ por $96 \mathrm{~h}$. O índice de proteólise primária foi determinado pelo método de Kjeldahl. Considerando o efeito do tempo de estocagem na multiplicação de Pseudomonas spp., observou-se que nas baixas populações iniciais $\left(2 \log \mathrm{CFU} \mathrm{mL} \mathrm{m}^{-1}\right)$ houve diferença significativa na multiplicação bacteriana apenas de $0 \mathrm{~h}$ para $24 \mathrm{~h}$, mantendo-se estável ao longo das 96 horas de estocagem. Quando uma população inicial mais alta $\left(6 \log\right.$ UFC $\left.\mathrm{mL}^{-1}\right)$ foi estocada, não observouse diferença significativa entre o tempo zero e os demais testados. Em relação ao efeito do tempo de estocagem no índice de proteólise, não foi encontrada diferença significativa neste índice, nas amostras com inóculo inicial de 2 e $6 \log$ UFC $\mathrm{mL}^{-1}$ de Pseudomonas spp. Quando foi analisado o efeito da temperatura de estocagem na multiplicação de Pseudomonas spp., houve diferença significativa apenas entre $2^{\circ} \mathrm{C}$ e $8^{\circ} \mathrm{C}$ depois de $96 \mathrm{~h}$ de estocagem com inóculo inicial de $2 \log \mathrm{UFC} \mathrm{mL} \mathrm{m}^{-1}$. Se for considerado o efeito da temperatura sobre a proteólise, houve diferença no inóculo $2 \log \mathrm{UFC} \mathrm{mL}^{-1}$ onde a proteólise primária com 24 horas foi menor a $2^{\circ} \mathrm{C}$ que a $8^{\circ} \mathrm{C}$. Baixas temperaturas ou menor tempo de estocagem não tiveram influência na contagem de Pseudomonas spp. ou no índice de proteólise primária quando as amostras continham maior contaminação. Em baixas contagens iniciais de Pseudomonas spp., o menor tempo de estocagem testado influenciou no controle populacional, e associado a redução na temperatura de estocagem, foram observados menores índices de proteólise.

Palavras-chave: Estocagem. Protease. Psicrotrófico. Qualidade.

The storage of refrigerated raw milk (RRM) for long periods is problematic for maintaining its quality as well as that of its derivatives. The spoilage of milk occurs because of the growth of psychrotrophic microorganisms that affects the milk quality (SILVA et al., 2011). The psychrotrophic bacteria found in milk are mostly Gram-negative, originated from the environment and milking equipments (FAGUNDES et al., 2006; SILVA et al., 2011). This increased microbial population is due to poor hygienic conditions during milking (SILVA et al., 2011). The psychrotrophic bacteria, from a minimum population of $10^{6}-10^{7}(6-7 \mathrm{log})$ colony forming units (CFU) $\mathrm{mL}^{-1}$ produce proteases and/or thermoresistant extracellular lipases which reduces the quality as well as the shelf life of the milk as evidenced by changes in the taste, smell and appearance, loss of consistency and gelling (ARCURI et al., 2008).

Pseudomonas spp. are Gram-negative psychrotrophic bacteria commonly isolated from RRM (ARCURI et al., 2008; FAGUNDES et al., 2006; NEUBECK et al., 2015; PINTO et al., 2006; XIN et al., 2017) because of its higher multiplication capacity in a refrigerated environment (KUMARESAN et al., 2007).

The production of enzymes such as proteases, lipases, and phospholipases by various Pseudomonas spp. are affected by temperature, oxygen availability, environmental factors, $\mathrm{pH}$, and substrate concentration, as well as the growth stage of the microorganism (NUÑEZ; NUÑEZ, 1983). Enzyme production by Pseudomonas spp. strains occurs mainly at the end of the log phase of cell growth and at sub-optimal temperatures (MAHIEU, 1991). Hence, our aim was to assess the multiplication capacity and proteolytic activity of different Pseudomonas spp. cell counts isolated from RRM under different storage temperature for $96 \mathrm{~h}$.

Pseudomonas spp. studied in this experiment were isolated under aseptic conditions from raw milk samples stored in cooling tanks from five dairy 
farms, in Parana State, Brazil (ALMEIDA et al., 2017). Samples were kept in styrofoam box with reusable ice packs until analysis. The Pseudomonas spp. strains were isolated from cephalothin-sodium fusidate-cetrimide (CFC) agar-base (Himedia, Mumbai, India) by incubation at $30^{\circ} \mathrm{C}$ for $48 \mathrm{~h}$ (FAGUNDES et al., 2006). The isolated strains were later stored at $-20^{\circ} \mathrm{C}$ in Brain Heart Infusion (BHI) broth (Himedia, Mumbai, India) containing $40 \%$ glycerol.

For confirming the genus Pseudomonas spp., ten strains were selected and identified by polymerase chain reaction (PCR) using forward PA-GS-F (GACGGGTGAGTAATGCCTA) and reverse PAGS-R (CACTGGTGTTCCTTCCTATA) primers which amplified the specific genus region on 16S rRNA (618 bp) and amplification conditions described by Spilker et al. (2004).

Bacterial genomic DNA was extracted using the Wizard Genomic DNA Purification Kit (Promega Corporation, Madison, USA) following the manufacturer's instructions. The isolated DNA was stored at $-80^{\circ} \mathrm{C}$. The extracted genetic material was subjected to PCR using the protocol described by Spilker et al. (2004) with modifications. Reactions were composed of a total of $25 \mu \mathrm{L}$ consisting of $15.8 \mu \mathrm{L}$ water, $2 \mu \mathrm{L}$ of DNA (100 ng/uL), $2.5 \mu \mathrm{L}$ of 10x buffer, $1.5 \mu \mathrm{L} \mathrm{MgCl}_{2}(25 \mathrm{mM}), 2.0 \mu \mathrm{L}$ dNTPs (2.5 mM), $0.5 \mu \mathrm{L}(0.5 \mathrm{rM})$ of each oligonucleotide (PA-GS-F and PA-GS-R) as initiators, and 1.0 U $(0.2 \mu \mathrm{L})$ of GoTaq ${ }^{\circledR}$ DNA polymerase (Invitrogen, CA, USA).

The PCR was carried out in a thermocycler (Veriti ${ }^{\circledR}$ 96-Well, Applied Biosystems ${ }^{\mathrm{TM}}$, USA) using the following cycling parameters: $95^{\circ} \mathrm{C}$ for $2 \mathrm{~min}, 39$ cycles of $95^{\circ} \mathrm{C}$ for $40 \mathrm{~s}, 54^{\circ} \mathrm{C}$ for $30 \mathrm{~s}$, $72^{\circ} \mathrm{C}$ for $45 \mathrm{~s}$, and one final cycle of $72^{\circ} \mathrm{C}$ for $7 \mathrm{~min}$. Ultrapure water was used as the negative control and DNA from the strain $P$. aeruginosa (ATCC 27853), P. fluorescens (ATCC 13525) and P. putida (ATCC 31483) were used as positive controls. The PCR product was subjected to agarose gel $(1 \%)$ electrophoresis, and the gel was stained with Sybr
Safe (Invitrogen, CA, USA), followed by photodocumentation under ultraviolet light.

From eighth strains confirmed to be Pseudomonas spp., three were used for the experiment to verify if they are proteolytic and the effect of storage time and temperature on their behavior. Strains of Pseudomonas spp. stored at $-20^{\circ} \mathrm{C}$ were inoculated in $200 \mathrm{~mL}$ of $12 \%$ reconstituted whole milk (Nestlê, São Paulo, Brazil) (SANTOS et al., 2010) and incubated at $21^{\circ} \mathrm{C}$ for $48 \mathrm{~h}$. Subsequently, the number of viable cells of Pseudomonas spp. was determined by surface plating on CFC agar-base, at $30^{\circ} \mathrm{C}$ for $48 \mathrm{~h}$ (FAGUNDES et al., 2006). After reaching the required bacterial cell count, decimal dilutions were made in $0.85 \%$ saline solution to obtain final concentrations of $2 \log \left(10^{2}\right)$ and $6 \log \left(10^{6}\right) \mathrm{CFU}$ $\mathrm{mL}^{-1}$. Each selected dilution was immediately used to set up cultures.

Aliquots of $400 \mathrm{~mL}$ of reconstituted whole milk were sterilized at $121^{\circ} \mathrm{C}$ for $15 \mathrm{~min}$, mixed with $4 \mathrm{~mL}$ of the Pseudomonas inocula previously prepared (2 and $6 \log \mathrm{CFU} \mathrm{mL} \mathrm{m}^{-1}$ ) and incubated at $2^{\circ} \mathrm{C}, 4^{\circ} \mathrm{C}$, and $8^{\circ} \mathrm{C}$ for 96 h. Pseudomonas spp. enumeration and determination of proteolysis indices were carried out every $24 \mathrm{~h}$ in duplicate and triplicate, respectively, and time zero was considered as negative control. Three experiments were carried out with the three strains confirmed to be Pseudomonas spp.

The two final concentrations used in this research were selected in order to simulate, first, a lower Pseudomonas spp. population (2 $\log \mathrm{CFU} \mathrm{mL} \mathrm{mL}^{-1}$ ) and second, a milk with a minimum population of $6 \mathrm{log}$ $\mathrm{CFU} \mathrm{mL} \mathrm{m}^{-1}$ to produce thermoresistant extracellular enzymes (ARCURI et al., 2008; MAHIEU, 1991).

The temperature of $4^{\circ} \mathrm{C}$ was selected to simulate Brazilian's regulations temperature in raw milk at dairy farms (BRASIL, 2011). Milk storage at 2 ${ }^{\circ} \mathrm{C}$ and $8^{\circ} \mathrm{C}$ were related (ALMEIDA et al., 2017) as usual in RRM and some authors had detected proteolytic activity at these temperatures, even in small psychrotrophic counts (HARYANI et al., 2003; WIKING et al., 2002). 
The milk samples inoculated with Pseudomonas spp. were diluted in $0.85 \%$ saline solution and cultured by surface plating on CFC agar-base at $30^{\circ} \mathrm{C}$ for $48 \mathrm{~h}$ (FAGUNDES et al., 2006).

To evaluate proteolysis, the protein fractions were determined by the Kjeldahl method (AOAC, 2000), estimating the total nitrogen content (TN) and non-casein nitrogen (NCN) (VIANNA; GIGANTE, 2010). The primary proteolysis index was determined from the NCN/TN ratio.

The results obtained were subjected to Tukey's test at $5 \%$ significance $(p<0.05)$ with the support of the software Statistica 13.0 (STATSOFT, OK, USA).
When taking into account the effect of storage time (96 h) in Pseudomonas spp. counting, it was found that the initial population of $2 \log \mathrm{CFU}$ $\mathrm{mL}^{-1}$, when stored at $2^{\circ} \mathrm{C}, 4^{\circ} \mathrm{C}$, and $8^{\circ} \mathrm{C}$, showed significant difference in growth rates only from 0 $\mathrm{h}$ to $24 \mathrm{~h}(p<0.05)$ (Table 1), keeping at the same levels along $96 \mathrm{~h}(\mathrm{p}>0.05)$. This result indicates that there was Pseudomonas spp. multiplication in the first $24 \mathrm{~h}$, emphasizing the importance in reducing the storage time to control Pseudomonas spp. growth in RRM, contributing to lower protease sinthesis and better milk and dairy products quality. Santos et al. (2010) reported that the storage of RRM for periods longer than $48 \mathrm{~h}$ is detrimental for milk quality and its derivative products, due to the increase in psychrotrophic microorganism count, attesting the fact that longer the storage time, the higher the bacterial count.

Table 1. Pseudomonas spp. counting* $\left(\log \mathrm{CFU} \mathrm{mL} \mathrm{m}^{-1}\right)$ in sterile whole milk following initial inoculation of 2 and 6 $\log \mathrm{CFU} \mathrm{mL} \mathrm{m}^{-1}$ incubated at $2^{\circ} \mathrm{C}, 4^{\circ} \mathrm{C}$ and $8^{\circ} \mathrm{C}$ for $96 \mathrm{~h}$.

\begin{tabular}{lcccccl}
\hline $\begin{array}{l}\text { Initial population } \\
\left(\mathbf{C F U} \mathbf{~ m L}^{-1}\right)\end{array}$ & \multirow{2}{*}{$\mathbf{T}^{\mathbf{0}} \mathbf{C}$} & 0 & 24 & 48 & 72 & 96 \\
\hline \multirow{3}{*}{$2 \log$} & 2 & $2.3^{\mathrm{b}}$ & $5.1^{\mathrm{a}}$ & $5.2^{\mathrm{a}}$ & $5.5^{\mathrm{a}}$ & $5.5^{\mathrm{a}, \mathrm{B}}$ \\
& 4 & $2.3^{\mathrm{b}}$ & $4.7^{\mathrm{a}}$ & $5.4^{\mathrm{a}}$ & $5.7^{\mathrm{a}}$ & $5.8^{\mathrm{a}, \mathrm{A}, \mathrm{B}}$ \\
& 8 & $2.3^{\mathrm{b}}$ & $6.2^{\mathrm{a}}$ & $6.4^{\mathrm{a}}$ & $6.4^{\mathrm{a}}$ & $7.0^{\mathrm{a}, \mathrm{A}}$ \\
\hline \multirow{3}{*}{$6 \log$} & 2 & 6.6 & 6.6 & 7.1 & 7.2 & 7.1 \\
& 4 & 6.6 & 8.2 & 7.8 & 7.6 & 7.9 \\
& 6 & 6.6 & 7.7 & 8.1 & 8.5 & 9.5 \\
\hline
\end{tabular}

*average of three experiments

${ }^{\mathrm{A}, \mathrm{B}}$ Capital superscripted letters in the same column indicate significant differences $(p<0.05)$ among the incubation temperature, at the same time point, and the same inoculum.

a,b,c Small superscripted letters in the same line indicate significant differences $(p<0.05)$ among the different incubation times, at the same temperature, and the same inoculum.

When a higher initial population was incubated (6 $\log \mathrm{CFU} \mathrm{mL} \mathrm{m}^{-1}$ ), it was not observed a significant difference $(p>0.05)$ between time zero and the others times tested (Table 1), stressing the relevancy of low initial Pseudomonas spp. populations in milk prior to the refrigeration. Researches showed high counts of Pseudomonas spp. in refrigerated raw milk, with populations between 4 and $6 \log \mathrm{CFU}$ $\mathrm{mL}^{-1}$ (ALMEIDA et al., 2017; FAGUNDES et al., 2006). Related to the effect of storage time in proteolysis index, it was not observed a significant difference $(p>0.05)$ in samples inoculated with 2 or $6 \log$ CFU mL m $^{-1}$ Pseudomonas spp. (Table 2). Studies assessing the time and refrigeration temperature effects on the growth of psychrotrophic bacteria in milk, indicate that raw milk with high counts of psychrotrophic and proteolytic psychrotrophic bacteria do not necessarily have more elevated proteolytic activity compared to samples having lower counts (SANTOS et al., 2010). 
Table 2. Primary proteolysis (\%)* of sterile whole milk inoculated with Pseudomonas spp. (2 and $\left.6 \log \mathrm{CFU} \mathrm{mL}^{-1}\right)$ incubated at $2^{\circ} \mathrm{C}, 4^{\circ} \mathrm{C}$ and $8^{\circ} \mathrm{C}$ for $96 \mathrm{~h}$.

\begin{tabular}{lcccccc}
\hline $\begin{array}{l}\text { Initial population } \\
\left(\mathbf{C F U} \mathbf{~ m L}^{-1}\right)\end{array}$ & $\mathbf{T}^{\mathbf{0}} \mathbf{C}$ & 0 & 24 & Time (hours) & \\
\hline \multirow{3}{*}{$2 \log$} & 2 & 4.44 & $7.65^{\mathrm{B}}$ & 7.67 & 8.25 & 5.41 \\
& 4 & 6.10 & $9.71^{\mathrm{A}, \mathrm{B}}$ & 7.77 & 8.70 & 6.29 \\
& 8 & 7.83 & $10.64^{\mathrm{A}}$ & 10.21 & 9.58 & 5.36 \\
\hline \multirow{3}{*}{$6 \log$} & 2 & 5.67 & 8.41 & 9.61 & 8.51 & 5.21 \\
& 4 & 6.27 & 7.08 & 7.21 & 8.94 & 4.20 \\
& 8 & 9.45 & 8.42 & 9.44 & 8.80 & 6.09 \\
\hline
\end{tabular}

*average of three experiments

${ }^{A, B}$ Capital superscripted letters in the same column indicate significant differences $(p<0.05)$ among the incubation temperature, at the same time point, and the same inoculum.

When we analyzed the influence of storage temperature of each inoculum for the same period of incubation on the bacterial multiplication, there was a significant difference $(p<0.05)$ in the Pseudomonas spp. population only between $2^{\circ} \mathrm{C}$ and $8^{\circ} \mathrm{C}$ after $96 \mathrm{~h}$ of milk storage with $2 \mathrm{log}$ Pseudomonas spp. CFU $\mathrm{mL}^{-1}$ inocula. Thus, in this study, the storage at $2^{\circ} \mathrm{C}$ was enough to control bacterial growth only at the lower inoculum tested until $96 \mathrm{~h}$, indicating, again, the importance of lower initial counts of Pseudomonas spp. Pinto et al. (2006) evaluated milk samples inoculated with $4 \log \mathrm{CFU} \mathrm{mL}^{-1}$ of $P$. fluorescens at 2, 4, 7 and 10 ${ }^{\circ} \mathrm{C}$ and found that the temperatures of $2{ }^{\circ} \mathrm{C}$ and $4{ }^{\circ} \mathrm{C}$ were effectives to control bacterial growth after 24 $\mathrm{h}$ of incubation. After $48 \mathrm{~h}$, a higher growth rate was observed in samples stored at higher temperatures. We asserted that even in refrigeration temperatures proposed by Brazilian legislation (BRASIL, 2011), a loss of quality in raw milk will occur if the initial contamination is not effectively controlled.

If we consider the temperature effect within the same time and inoculum, there were significant differences $(p<0.05)$ in the primary proteolysis index at the inoculum of $2 \log \mathrm{CFU} \mathrm{mL} \mathrm{mL}^{-1}$ of Pseudomonas spp., where the primary proteolysis at $24 \mathrm{~h}$ was lower at $2^{\circ} \mathrm{C}$ than at $8^{\circ} \mathrm{C}$. Thus, lower refrigeration temperatures contribute to lower proteolysis index only until $24 \mathrm{~h}$ of storage, when there is a small initial population of Pseudomonas spp., highlighting, once more, the importance of minimal storage time to keep the milk and dairy products quality. Kumaresan et al. (2007), comparing psychrotrophic growth in different incubation temperatures, observed that milk storage at $2{ }^{\circ} \mathrm{C}$ resulted in lower bacterial growth and lower proteolytic and lipolytic activity.

At the primary proteolysis, called Extension Index, micelles of casein are cleaved into peptides, thereby solubilizing the casein. The greater the primary proteolysis, the more soluble peptides will be released from the casein, being $\kappa$-casein and glycomacropeptides the most important. The fraction $\kappa$-casein located at the surface of the casein micelle is preferentially hydrolyzed by psychrotrophic bacterial proteases and this hydrolysis causes the development of bitter taste and increases the viscosity, with eventual gel formation in ultra-high temperature milk, when subjected to long storage period (FOX; MCSWEENEY, 1998).

Thus, low temperatures or short storage time had no influence on Pseudomonas spp. enumeration or in the primary proteolysis index when high initial contaminations are observed. At lower Pseudomonas spp. initial population, the smaller storage time tested influenced the population control, and linked with the reduction in the storage temperature, lower proteolysis index were observed. 


\section{References}

ALMEIDA, K. M.; BRUZAROSKI, S. R.; ZANOL, D.; MELO, M.; SANTOS, J. S.; ARAGON ALEGRO, L. C.; SANTANA, E. H. W. Pseudomonas spp. and $P$. fluorescens: population in refrigerated raw milk. Ciência Rural, Santa Maria, v. 47, n. 1, p. 1-5, 2017.

ASSOCIATION OF OFFICIAL ANALYTICAL CHEMISTS - AOAC. Official methods of analysis of AOAC International. 2000. 17th ed. Gaithersburg, Maryland: AOAC International.

ARCURI, E. F.; SILVA, P. D. L.; BRITO, M. A. V. P.; BRITO, J. R. F.; LANGE, C. C.; MAGALHÃES, M. M. A. Counting, isolation and characterization of psychrotrophic bacteria from refrigerated raw milk. Ciência Rural, Santa Maria, v. 38, n. 8, p. 2250-2255, 2008.

BRASIL. Ministério da Agricultura, Pecuária e Abastecimento: Instrução Normativa 62, de 29 de dezembro de 2011. Aprova o regulamento técnico de produção, identidade e qualidade do leite tipo A, o regulamento técnico de identidade e qualidade de leite cru refrigerado, o regulamento técnico de identidade e qualidade de leite pasteurizado e o regulamento técnico da coleta de leite cru refrigerado e seu transporte a granel. Diário Oficial [da República Federativa do Brasil], Brasília, 30 dez. 2011. Seção 1, p. 6.

FAGUNDES, C. M.; FISCHER, V.; SILVA, W. P.; CARBONERA, N.; ARAÚJO, M. R. Presença de Pseudomonas spp. em função de diferentes etapas da ordenha com distintos manejos higiênicos e no leite refrigerado. Ciência Rural, Santa Maria, v. 36, n. 2, p. 568-572, 2006.

FOX, P. F.; McSWEENEY, P. L. H. Dairy chemistry and biochemistry. Press: Tullamore, Ireland, 1998. 478 p.

HARYANI, S.; DATTA, N.; ELLIOTT, A. J.; DEETH, H. C. Production of proteinases by psychrotrophic bacteria in raw milk stored at low temperature. Australian Journal of Dairy Technology, North Melbourne, v. 58, n. 1, p. 1520, 2003.

KUMARESAN, G.; ANNALVILLI, R.; SIVAKUMAR, K. Psychrotrophic spoilage of raw milk at different temperatures of storage. Journal of Applied Sciences Research, Amman-Jordan, v. 3, n. 1, p. 1383-1387, 2007.

MAHIEU, H. Modificaciones de la leche después de su recogida. In: LUQUET, F. M. Leche y productos lácteos. La leche de la mama a la lechería. Zaragoza: Acribia, p. 181-22,1991.
NEUBECK, M.; BAUR, C.; KREWINKEL, M.; STOECKEL, M.; KRANZ, B.; STRESSLER, T. FISCHER, L.; HINRICHS, J.; SCHERER, S.; WENNING, M. Biodiversity of refrigerated raw milk microbiota and their enzymatic spoilage potential. International Journal of Food Microbiology, Torino, v. 211, p. 57-65, 2015.

NUÑEZ, M.; NUÑEZ, J. A. Proteasas de psicrotrofos Gram negativos. Efectos sobre la leche y los productos lácteos. Revista Española de Lecheria, Madrid, v. 130, n. 1, p. 251-260,1983.

PINTO, C. L. O.; MARTINS, M. L.; VANETTI; DANTAS, M. C. Qualidade microbiológica de leite cru refrigerado e isolamento de bactérias psicrotróficas proteolíticas. Food Science and Technology, Campinas, v. 26, n. 3, p. 645-651, 2006.

SANTOS, P. A.; SILVA, M. A. P.; MOREIRA, N, G.; BARROS, C. J.; OLIVEIRA, A. N.; NICOLAU, E. S. Evolução da proteólise do leite inoculado in vitro com Pseudomonas fluorescens. Boletim do Centro de Processamento de Alimentos, Curitiba, v. 28, n. 2, p. 313320, 2010.

SILVA, L. C. C.; BELOTI, V.; TAMANINI, R.; OVIDIO, L.; MATTOS, M. R.; ARRUDA, A. M. C. T.; PIRES, E. M. F. Rastreamento de fontes da contaminação microbiológica do leite cru durante a ordenha em propriedades leiteiras do Agreste Pernambucano. Semina: Ciências Agrárias, Londrina, v. 32, n. 1, p. 267276, 2011.

SPILKER, T.; COENYE, T.; VANDAME, P.; LIPUMA, J. J. PCR-Based assay for differentiation of Pseudomonas aeruginosa from other Pseudomonas species recovered from cystic fribrosis patients. Journal of Clinical Microbiology, Washington D.C., v. 42, n. 5, p. 20742079, 2004.

VIANNA, P. C. B.; GIGANTE, M. Physical chemical quality of the refrigerated raw milk added with carbon dioxide. Revista do Instituto Laticínio Cândido Tostes, Juiz de Fora, v. 375, n. 65, p. 51-59, 2010.

WIKING, L.; FRØST, M. B.; LARSEN, L. B.; NIELSEN, J. H. Effects of storage condition on lipolysis, proteolysis and sensory attribute in high quality raw milk. Milchwissenschaft, Kempten, v. 57, n. 4, p. 190194, 2002.

XIN, L.; ZHAOXU, M.; ZHANG, L.; CUI, Y.; HAN, $\mathrm{X}$; Y Y, H. The diversity and proteolytic properties of psychrotrophic bacteria in raw cows' milk from North China. International Dairy Journal, Edmonton, v.66, March, p. 34-41, 2017. 